\title{
Peculiarities of Development of Phytoplankton as an Indicator of the Ecological State in Modern Hydrochemical Conditions of Masrik River
}

\author{
Hambaryan L. R. ${ }^{1}$, Nalbandyan M. A. ${ }^{2}$, Poghosyan A. M. ${ }^{2}$ \\ ${ }^{1}$ Department of Ecology and Nature Protection, Yerevan State University, Yerevan, Armenia \\ ${ }^{2}$ Institute of Geological Sciences of the NAS Yerevan, Armenia
}

Email address:

lus-ham@yandex.ru (Hambaryan L. R.), marinen3@yahoo.com (Nalbandyan M. A.), ani-poghosyan@live.com (Poghosyan A. M.)

\section{To cite this article:}

Hambaryan L. R., Nalbandyan M. A., Poghosyan A. M.. Peculiarities of Development of Phytoplankton as an Indicator of the Ecological State in Modern Hydrochemical Conditions of Masrik River. American Journal of Environmental Protection. Special Issue: Applied Ecology: Problems, Innovations. Vol. 4, No. 3-1, 2015, pp. 44-50. doi: 10.11648/j.ajep.s.2015040301.18

\begin{abstract}
This paper is related to the study of hydro chemical characteristics and the phytoplankton of the river Masrik. For planktonic study, algae were selected from 3 sampling sites: two from tributaries of the river and one from the river Masrik. Hydro chemical monitoring includes 9 sampling points. The study includes the spring of 2014 and the summer of 2013. According to the hydro chemical research of water, the $\mathrm{pH}$ ranged from 6.5-7.3. In 2014, the $\mathrm{pH}$ was lower compared with the spring of the previous year. Among tested anions, in some areas, relatively high level of sulfates were reached $80-120 \mathrm{mg} / \mathrm{L}$. Total hardness ranged from 0,6-5,6 mg-eqv/L, and the total mineralization - was ranged from 60 to $430 \mathrm{mg} / \mathrm{L}$. Studies of heavy metals revealed a relatively high content of lead, nickel and chromium in water. Visual assessment revealed a significant organic pollution of Masrik river, which confirmed by high levels of BOD5 in water in 2014. In Masrik river mainly 3 groups of algae were detected: diatoms, green and blue-green. Dominant group was diatoms. Dominated types of algae were $\beta$ mezosaprobs (about 53\%), which indicated the average level of organic pollution of the river. As a part of the green algae Spirogira sp. was found. The maximum number of phytoplankton in the investigated areas was 16,854,000 cells / L, and the biomass was $162 \mathrm{~g} / \mathrm{m} 3$, the minimum rates - respectively 464000 cells $/ 1$ in and $2.8 \mathrm{~g} / \mathrm{m} 3$ for biomass. In water samples well developed whorls algae of the genus Chara were found, which presence indicates anthropogenic pollution. Thus, in a more acidic environment, the presence of high levels of organic pollution creates favorable conditions for the growth and development not only phytoplankton such as algae, but also for macrophytes, which indicates the reduction of ecological status of rivers.
\end{abstract}

Keywords: Ecological Monitoring, Water Quality, Saprobity, Phytoplankton, Hydrochemical Characteristics

\section{Introduction}

The main purpose of this work is an investigation of hydro chemical features, quantitative and qualitative compounds of phytoplankton in the river Masrik. This research is an example of interdisciplinary study of aquatic ecosystems, that are under the impact of numerous anthropogenic factors (agriculture, livestock, domestic and waste water), including mining (particularly gold) industry.

Study of water quality in the process of environmental monitoring involves the use of chemical, physical and biological parameters.

Rivers, especially in industrialized areas most exposed to pollutants such as heavy metals or hazardous organic pollutants. It is known that the water quality can be affected by chemicals such as $\mathrm{pH}$, hardness, and oxygen. The changes in concentration can increase the toxicity of pollutants. Biomass of phytoplankton is considered as one of the most promising methods for assessing aquatic ecosystems in terms of the functioning of the primary autotrophic link. Data of phytoplankton in rivers indicate the presence and transformation of pollution, and can characterize the level of self-purification of aquatic ecosystem. It is also known that in the process of contamination of aquatic ecosystems, the prevailable species saprobity shows the presence of organic pollution of water [11].

It is very important that hydrobionts have integral response to changes in environmental conditions, fluctuation of water 
quality, thus, complex hydroecological studies represent special value and scientific interest, allowing to evaluate the interaction and mutual influence of hydrochemical and hydrobiological indicators.

Masrik River flows into Sevan Lake, which has a great importance for social-economic development not only for Armenia, but also the neighboring countries, as a promising source of fresh water $[12,13]$. In this regard, the monitoring and research on the river water quality is important in terms of control of eutrophication processes and anthropogenic pollution of Lake Sevan ecosystems.

\section{Study Area and Methods}

The river Masrik flows through the territory of Ghegharkunik region. The river originates from the western slopes of the eastern part of the Sevan mountain ridge and flows into Sevan Lake. The Riverhead of Masrik river is at an altitude $2880 \mathrm{~m}$. The length of the river is $45 \mathrm{~km}$, catchment (watershed) area- $685 \mathrm{~km}$, the average slope in the upper reaches is $158 \%$. The annual average flow rate of the river is $5.38 \mathrm{~m}^{3} / \mathrm{sec}$.

Hydrochemical and hydrobiological studies were included spring and summer of 2013 and 2014. Hydrochemical monitoring includes 9 sampling points (fig.1). In the samples, major ions, biogenic compounds and some heavy metals were measured.

For studying planktonic algae 3 points were selected: 2 from tributaries of Masrik river-Sotk (point 2) and Aziz (point 5) - and the last one from downstream of the river (point 9). As a result of development gold mining industry in
Masrik river basin, especially in the basin of its tributary, the river waters characterized by an excessive intake of mineral suspended matter in them.
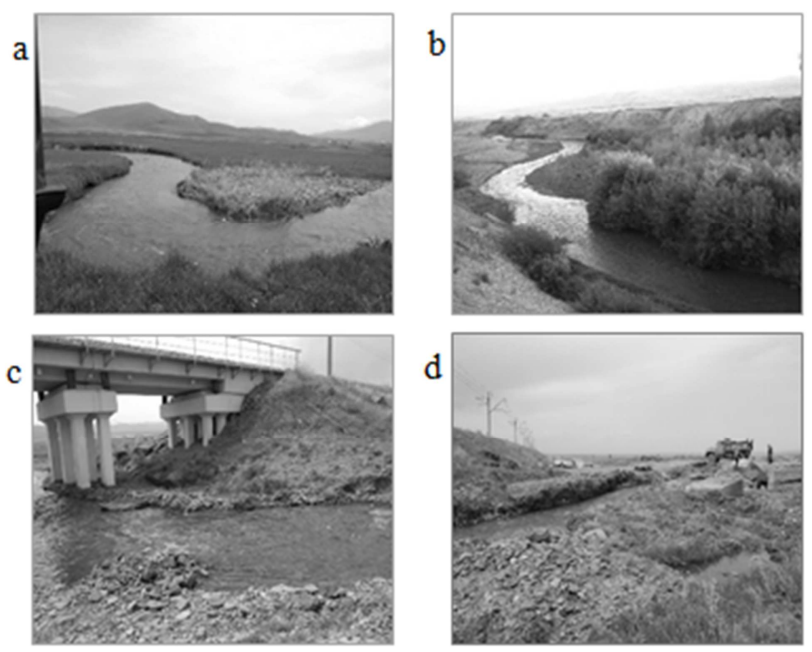

Photo 1. Photos of Sotk River (a), the main tributary of the River Masrik; River Masrik. (b); River Aziz (c), one of the left tributary of the River Masrik; the place on this tributary under the impact of the local man-made factor (d).

Mining waters characterized by high levels of electrical conductivity and salinity. These integrated indicators showed high level of mineralization in the water. Thus, the MPC of all ore elements, $\mathrm{Cu}, \mathrm{Zn}$ and $\mathrm{Ni}$ was exceeded. Along with elements that were mentioned above, in mining waters the sulfate ion is dominated and exceed MPC 4-5 times.
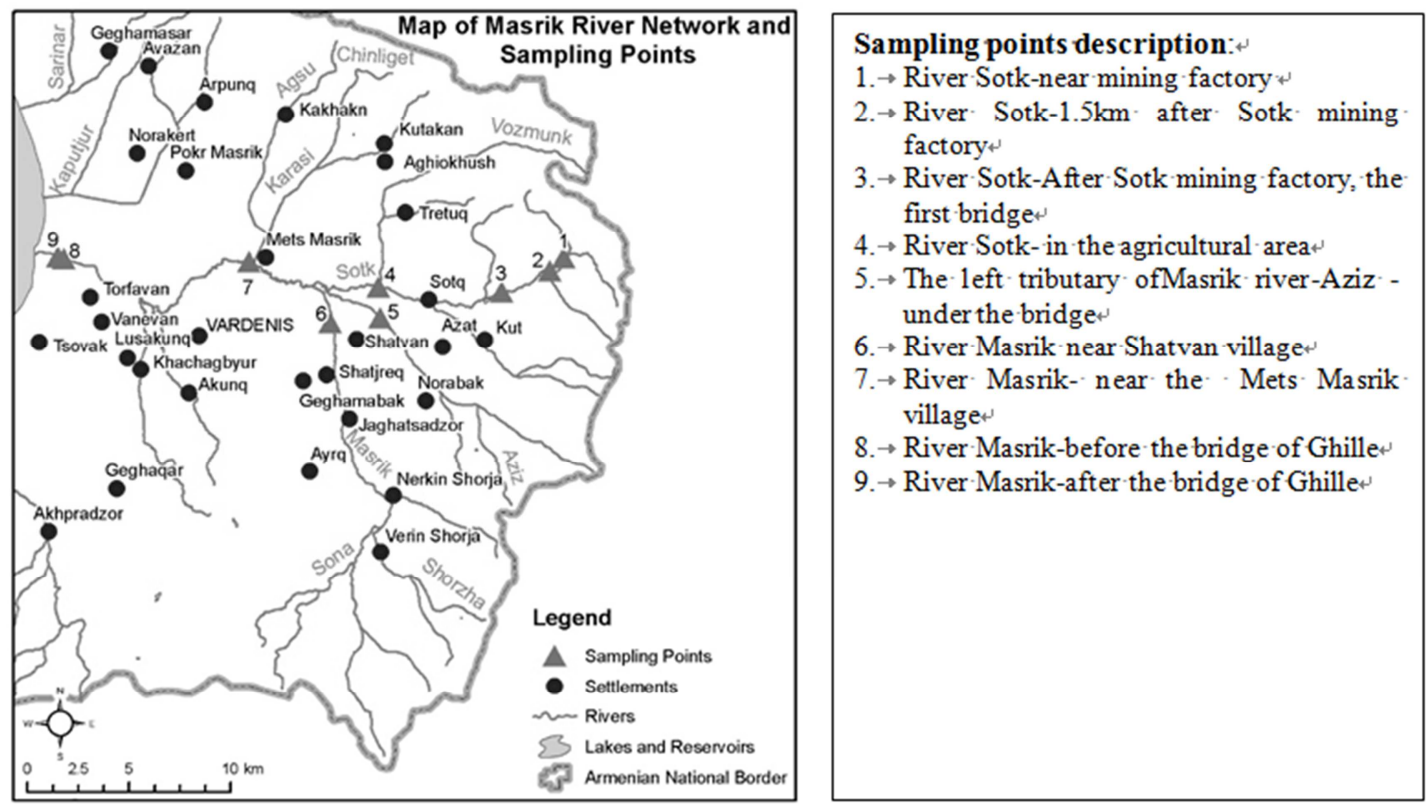

Fig. 1. The Map of Masrik River Network and Sampling Points

The MPC for $\mathrm{HCO}_{3}, \mathrm{NO}_{2}, \mathrm{SO}_{4}$ and $\mathrm{Mg}$ was exceeded as well [1].

At the same time, it should be noted that the carbonate mode of geochemical landscape promotes natural neutralization of pollution of sulfate ion.

The quality of Masrik river waters is an integrated indicator of the ecological impact of mining industry on the environment. During an assessment of the ecological status 
of waters, it should be aware that the origins of the river forms within the biochemical province, where in different substrates is present natural higher contents of the individual components, which means high natural geochemical background, due to the influence of ophiolite rocks $[9,10]$.

\subsection{Sampling Methods}

Before collecting of each sample, bottles were washed 3-4 times with testing water. The level of the bottled water samples met the requirements of samples selectionmaximum. Collection, preservation and processing of algae were conducted according to standard methodology adopted in hydrobiology [3].

\subsection{Chemical Analysis Methods}

The table 1 shows the list of methods that were used for the analysis of water samples.

Different determinants were used for clarifying the species of algae $[4,5,6,7]$. Quantitative analysis of phytoplankton samples produced in a Nageotte chamber $(\mathrm{V}=0.1 \mathrm{ml})$. The Nageotte chamber filled 7 times. Simultaneously with the determination of quantity, the measurement of cell volume of massive forms of phytoplankton was performed.

The Nageotte chamber filled 7 times. Simultaneously with the determination of quantity, the measurement of cell volume of massive forms of phytoplankton was performed.

The biomass was identified by individual volume of the cells for each type of phytoplankton in the sample. Relative weight of algae considered as 1 .

The biomass of $\mathrm{i}$ species are calculated using following formula.

Table 1. The methods for Determination of Different Elements and Compounds in Water

\begin{tabular}{|c|c|c|c|c|}
\hline $\mathbf{N}$ & Elements and Compounds & Methods of Determination & $\begin{array}{l}\text { Sensitivity of Analysis } \\
\text { Method }\end{array}$ & Links \\
\hline 1 & $\mathrm{Na}^{+}$ & Flame-photometric analysis & 0.1 & ISO 9964-3 \\
\hline 2 & $\mathrm{~K}^{+}$ & Flame-photometric analysis & 0.3 & ISO 9961-3 \\
\hline 3 & $\mathrm{Ca}^{2+}$ & Volumetric-trilonometric analysis & & ISO 6058 \\
\hline 4 & $\mathrm{Mg}^{2+}$ & Volumetric-trilonometric analysis & & ISO 7980 \\
\hline 5 & $\mathrm{Cl}^{-}$ & Volumetric method with silver nitrate & & ISO 9297 \\
\hline 6 & $\mathrm{SO}_{4}{ }^{2-}$ & Weights methods & & ISO 9280 \\
\hline 7 & $\mathrm{PO}_{4}^{3-}$ & Colorimetric method with ammonium molybdate & 0.01 & ISO 6878 \\
\hline 8 & $\mathrm{NO}_{3}^{-}$ & Colorimetric method with sodium salicilate & 0.2 & ISO $7890-3$ \\
\hline 9 & $\mathrm{NO}_{2}^{-}$ & Colorimetric method with Griess reagent & 0.01 & Ã̂̂̃̃NÒ 4192-82 \\
\hline 10 & $\mathrm{Ni}^{+}$ & Colorimetric method with dimethylglixime & 0.005 & ISO 8288 \\
\hline 11 & $\mathrm{Cr}$ & Colorimetric method with diphenylcloride & 0.005 & ISO 11083 \\
\hline 12 & $\mathrm{Cu}^{2+}$ & Polarographic method & 0.0005 & Instrument manual \\
\hline 13 & $\mathrm{~Pb}^{2+}$ & Polarographic method & 0.00005 & Instrument manual \\
\hline
\end{tabular}

$$
\mathrm{Bi}=\mathrm{NiVi} \text {, }
$$

where

Bi-the biomass of i species, Ni-its quantity, Vi-average volume of the cell.

For assessment the level of contamination of Masrik river water saprobien system of Kolkwitz and Marson were used, particularly modified by Zelinka and Marvana. For calculation of saprobioty steps, the list of algae were usedindicators of saprobioty [8].

\section{Results and Discussions}

\subsection{Hydrochemical Study of Masrik River Water}

According to hydrochemical research of water, the $\mathrm{pH}$ ranged from 6.5-7.3. Compared with the spring of the previous year in 2014, $\mathrm{pH}$ was lower. Total mineralization varied within the limits of $60-430 \mathrm{mg} / \mathrm{L}$, and water hardness averaged 0,6-5,6 mg-eqv/L. Moreover, it should be noted that the water of the river Sotk had higher salinity and hardness
(3-5,6 mg-eqv/L), and according to the classification described as moderately hard. According to its ionic composition, the water of Sotk river can be classified as a hydrocarbonate- calcium-magnesium, and the water of Masrik river - hydrocarbonate-sulphate-calcium-magnesiumsodium.

In 2014, BOD5 in different parts of watercourses of the river amounted respectively - 10.8 (at upper- Sotk inflow), 4.2 (on average) and 4.5 (lower) parts of the river Masrik, indicating a relatively high level of organic contamination of the waters of the river.

Modern research and evaluation of surface water quality, that are presented in the article are based on national standards adopted in 2011 and developed with point of view of the basin management of the river watershed. According to the assessment of the content of major ions, nutrients and heavy metals in the water, by the norms of surface water quality and by taking into account geochemical peculiarities of the basins, the classification of the pollution level of the waters of Masrik river were performed [2]. 

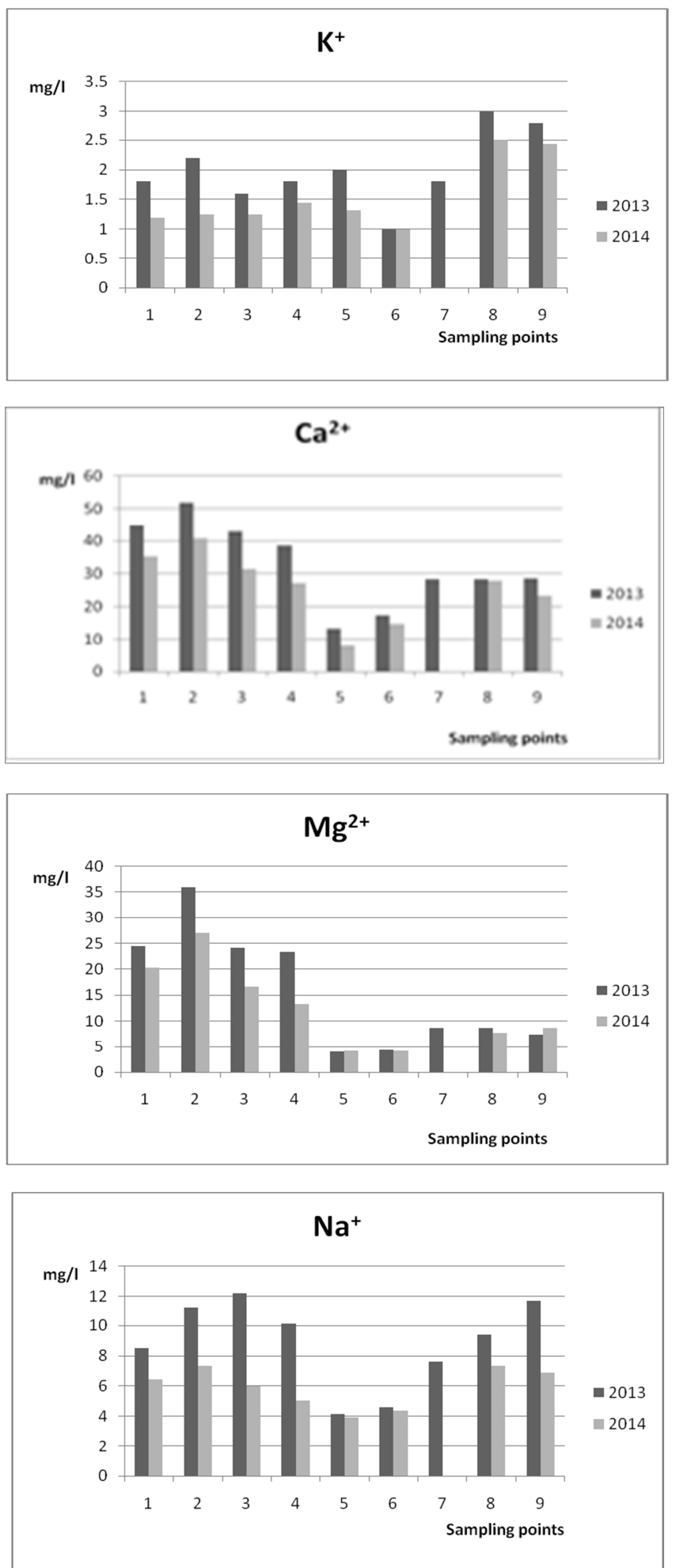

Fig. 2. The Level of Content of Cations in the Water of Masrik River in 2013 and 2014 .

Assessment of concentrations and the pollution level by $\mathrm{Na}, \mathrm{Cl}$ and $\mathrm{SO}_{4}$ the river water belongs to II class, by $\mathrm{K}, \mathrm{Ca}$ and $\mathrm{Mg}$ - to I class (fig. 2, 3). According to the evaluation of biogenic components $\mathrm{NH}_{4}$ and $\mathrm{NO}_{2}$ the river water belongs to II class, by $\mathrm{NO}_{3}$-to IV class, by $\mathrm{PO}_{4}$-in upper (R.Sotk) and in the middle part of the river Masrik-to II class, but in the lowest part, in the river mouth - to the III class (fig.4). For heavy metals the following results were revealed - by $\mathrm{Cu}-\mathrm{I}$ class, $\mathrm{Ni}$ and $\mathrm{Pb}$-II class, $\mathrm{Cr}$-III class (fig.5)
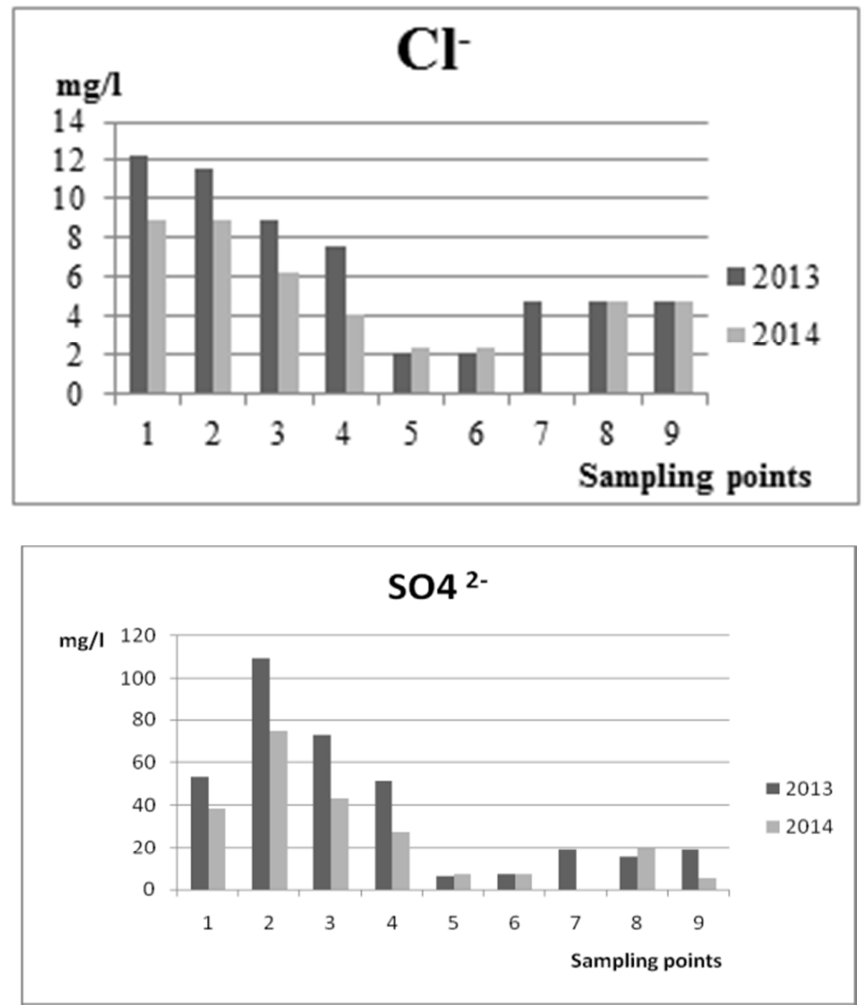

Fig. 3. The Level of Content of Anions in the Water of Masrik River in 2013 and 2014.
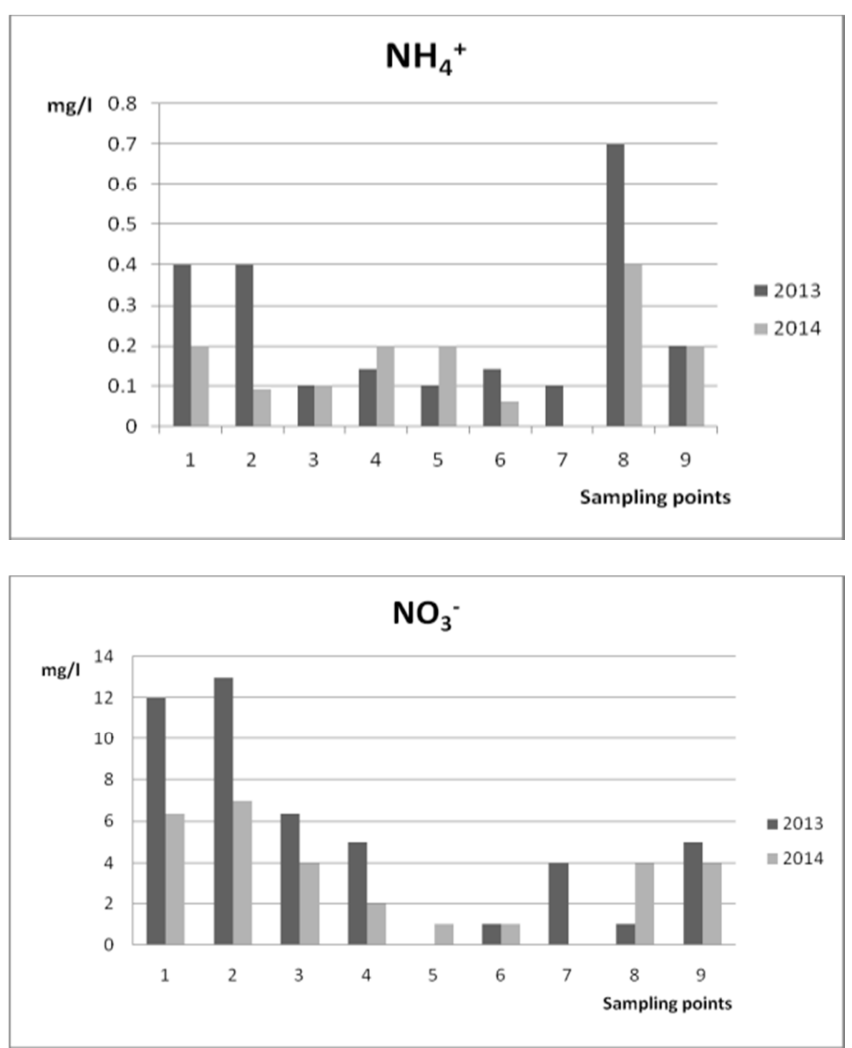

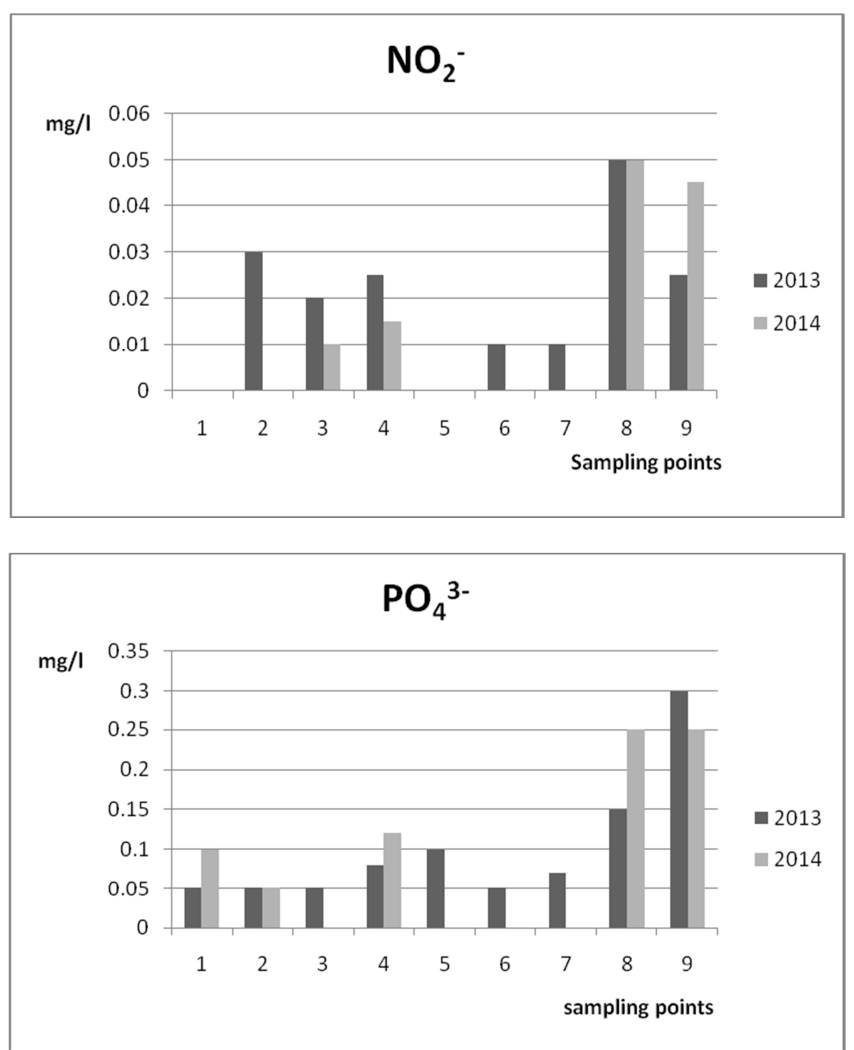

Fig. 4. The Level of Content of Biogen Compounds in the Water of Masrik River in 2013 and 2014
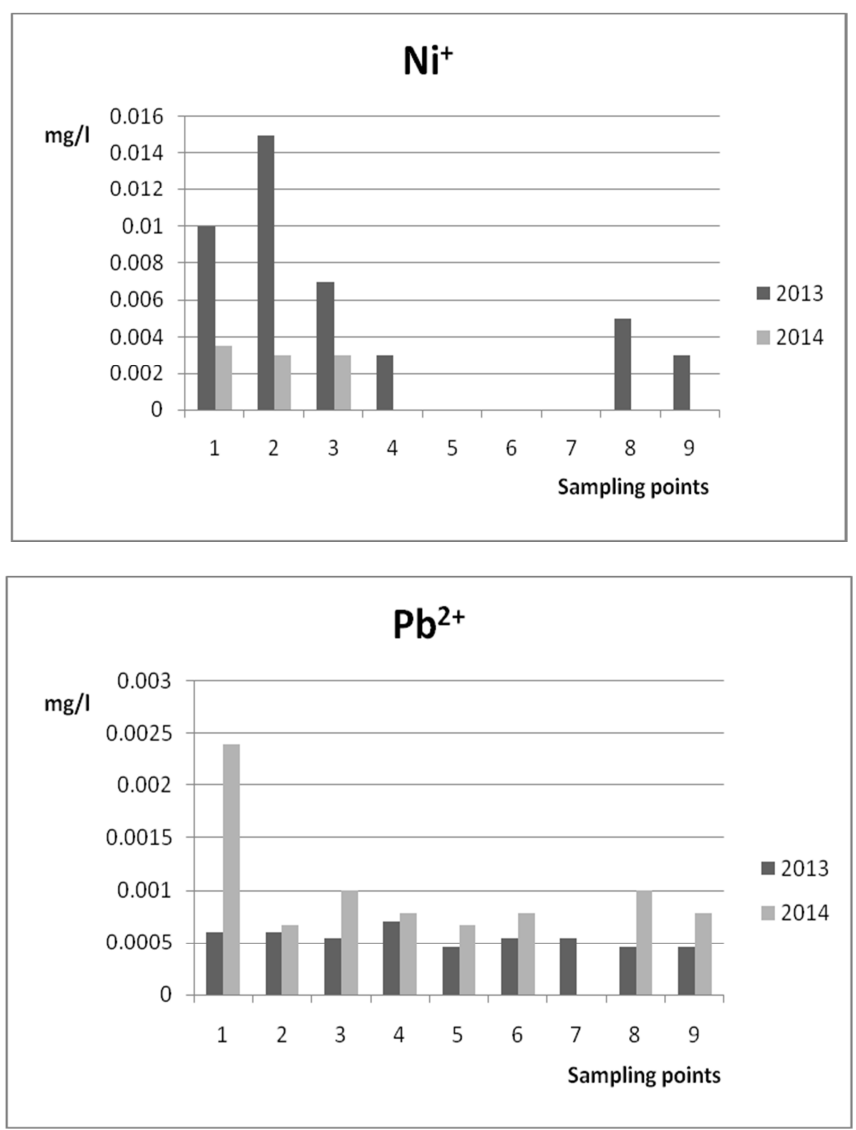
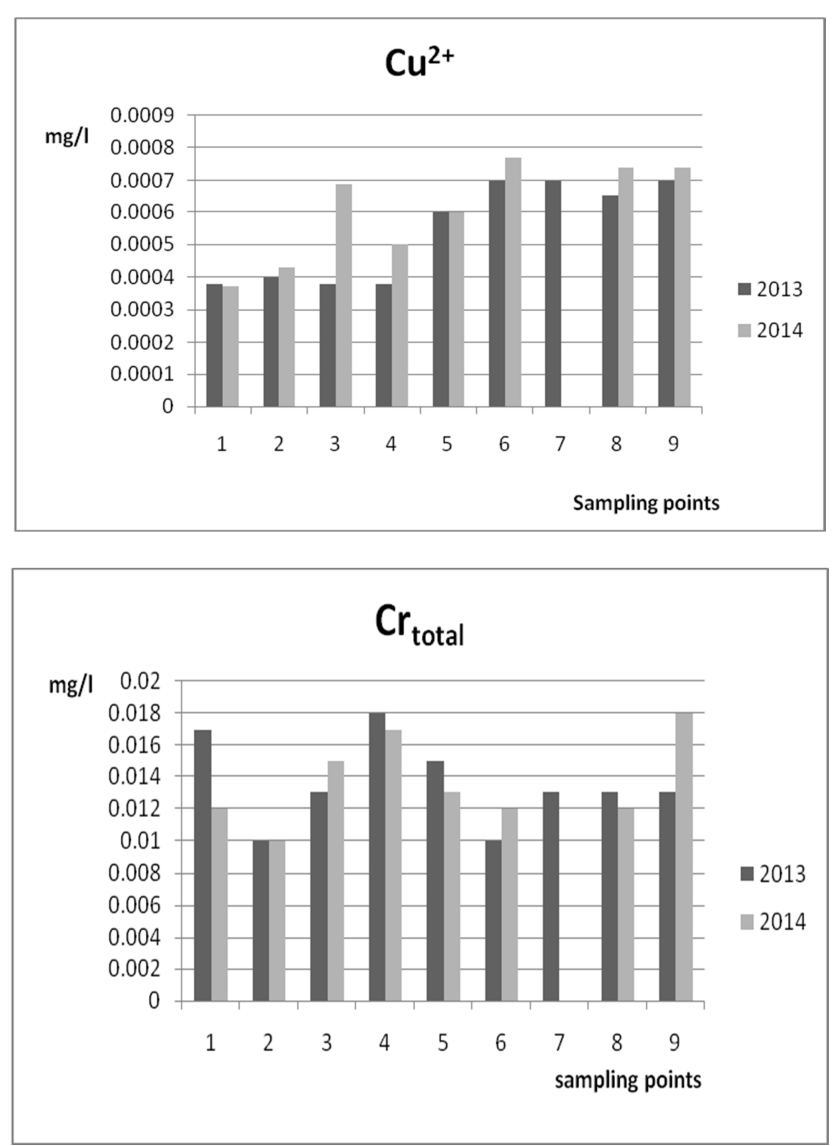

Fig. 5. The Level of Content of Heavy Metals in the Water of Masrik River in 2013 and 2014.

In the ores and rocks of Sotk ore deposit there are elements classified as a hazard of I and II class: respectively the group of $\mathrm{Cd}, \mathrm{Pb}, \mathrm{As}, \mathrm{Hg}, \mathrm{Zn}$ and the group of $\mathrm{Cu}, \mathrm{Co}, \mathrm{Ni}, \mathrm{Cr}, \mathrm{Mo}, \mathrm{Sb}$. Selected items in the mines are mainly presented as sulfide minerals which are not water resistant and are broken down in aerobic conditions forming higher acidic environment with a high mobility of releasing elements [9, 10]. Consideration of the content of heavy metals in ores shows the connection between the prevalence of this elements in ores and their high content in the waters of the river[9].

Qualitative and quantitative research on the composition of phytoplankton showed that the main communities were 3 groups of algae: diatoms, green and blue-green. Dominant group were diatoms. As a part of all groups of algae-dominated types were eutrophicators, $\beta$-mezosaprobs (about 53\%), indicating about the average level of organic pollution of the river.

As a part of the green algae Spirogira sp. was found, which ecology is not inherent to the environment of reoplankton, as these species are widespread in the slowly flowing and stagnant waters, forming a mass of slime. The prevalence of this type indicates the presence of fecal contamination in the water.

\subsection{Hydrobiological Study of the Water of Masrik River}

The maximum number of phytoplankton in the investigated areas was $16,854,000$ cells / 1 , and the biomass 
was $162 \mathrm{~g} / \mathrm{m}^{3}$, the minimum rates - respectively 464000 cells $/ 1$ in and $2.8 \mathrm{~g} / \mathrm{m}^{3}$ for biomass. High quantitative indicators of planktonic algae, also indicate the presence of favorable conditions for their mass development and active vegetation. In water samples were found well developed whorls algae of the genus Chara, which is not representative of the plankton and were not observed in the spring of last year, but their presence indicates technogenic pollution.

In a summer dominant group of phytoplankton were diatoms. They were $75 \%$ of the total phytoplankton and $79 \%$ of indicators of total biomass of phytoplankton of Masrikriver. (fig.6 ( a,b)). Dominant diatom species of the genera were: Stephanodiscus, Didimosphenia, Nitzhia, Synedra, Cocconeis, Navicula, Amphora, Diatoma, Ceratoneis, Cymbella, Fragilaria and Rhoicosphenia. In summer, maximum rates of diatoms was registered in the estuary of the river Masrik amounting by the number of 468,000 cells $/ 1$, and by biomass in June, in the middle reaches, reaching $5.6 \mathrm{~g} / \mathrm{m}^{3}$. High rates of biomass caused by the development of the macrocellular Cocconeisplacentula form, which is a boreal species, developing at a $\mathrm{pH}$ above 7 . This species is an indicator of polluted conditions and is characterizing beta mezosaprob level of contamination [14]

Blue-green algae in the studied period were in subdominant community, they were registered in all parts of the river. Quantitative indicators of blue-green algae were increased in August, the maximum indicators in numbering 164,000 cells $/ 1$ and $0.33 \mathrm{~g} / \mathrm{m}^{3}$, were found in the middle reaches of the river. The percentage of blue-green algae accounted for $19 \%$ of the size of the total population and $7 \%$ of the total biomass, respectively (Fig.6 (a,b)). They were mostly species of the genera Aphanothece, Microcystis, Phormidium, Merismopedia. These are mainly small-celled colonial toxic forms of algae.

Green algae were not observed in June. In August in the middle of the river were registered maximum values of green algae, which were amounted in the number of 132000 cells/1 and biomass $0.7 \mathrm{~g} / \mathrm{m}^{3}$. By quantitative indicators green algae were accounted for $6 \%$ of the total population and $10 \%$ of the total biomass of the community. (Fig.6 (a,b)). Among the green algae, especially in filamentous forms, many types are occurring and developing in polluted conditions. Phytoplankton acts as an absorber of heavy metals and other chemical substances [15]. The dominant species were Ankistrodesmusfalcatus, Dictiosphaerumpulchelum, Scenedesmusacuta, Oocystisparva, O. lacustris, Phacuslongicauta.

From the literature it is known that some species of the genus Scenedesmus are highly toxic and it is one of the most promising species for cultivation in the laboratory. Species of Scenedesmusgenus used for waste water treatment[16].

Ecological assessment of water quality of biomass of phytoplankton showed that the part of river in sampling point 9 appropriate to average clear water class.

Part of the river, particularly in sampling points 1-2 appropriate as a polluted water class, category of strongly polluted, and part of a river-sampling point 5 appropriate to the polluted water class, category extremely polluted.

It can be mentioned that the hydrochemical assessment of water corresponds to the environmental assessment of water quality of biomass of phytoplankton in points 9 and 2. In the point 5 the same water with hydro-chemical point of view refers to the less stained and observed maximum values of phytoplankton biomass associated with temporary anthropogenic impacts, which are formed the small artificial pound, that contributes an active vegetation of planktonic algae (Photo 1).
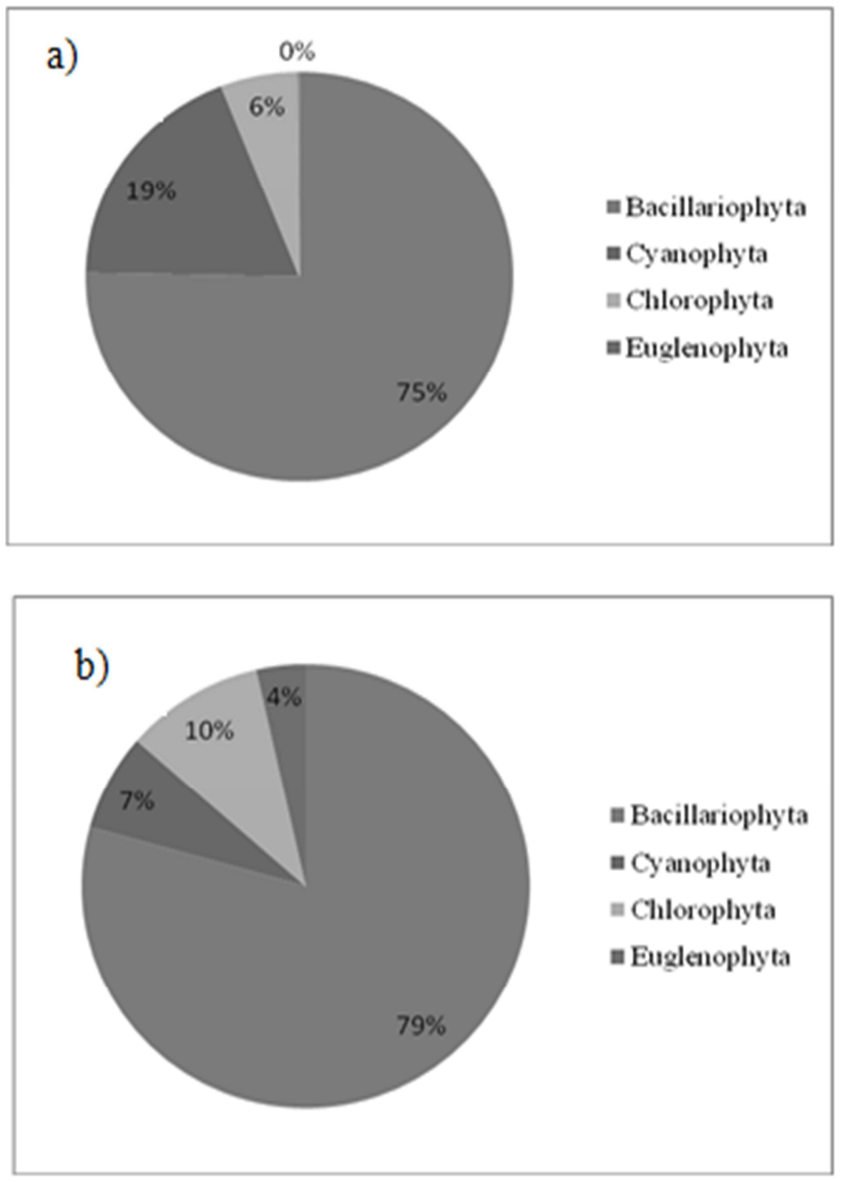

Fig. 6. Percentage of major groups of phytoplankton Masrik River, in terms of the quantity (a) and biomass (b), summer 2014.

This observation has a scientific interest in terms of prediction of environmental situation in the water in case of impact on the riverbed, which brings the changes of the water cycle and conditions.

\section{Conclusion}

Visual assessment of water samples revealed the presence of clusters of filaments of algae and peresistant inherent in municipal wastewater. These visual assessments revealed a significant organic pollution of river Masrik, which was confirmed by high levels of BOD5 in water.

According to the evaluation of hydrochemical characteristics, it can be concluded about the ongoing impact of Sotk gold deposit on the water quality of the river Masrik, 
that is expressed in a high level of sulfate ions in the water of the river Sotk (II class of pollution) and there is a stable high concentration of chromium along the entire length of the river to its confluence with Lake Sevan (III class of pollution). High concentrations of phosphate (III class) and nitrate (IV class) are the results of influence of domestic wastewater.

In the qualitative composition of phytoplankton, more than half (about 53\%) are $\beta$-mesosaprobic species-indices of the level of pollution. The presence of blue-green and green algae in the river Masrik also indicates the averagelevel of ecosystem pollution.

In terms of phytoplankton biomass, water quality of the river Masrik in different parts of the river, was changed by class - from satisfactorily clean up until contaminated, by category -from slightly contaminated to heavily contaminated.

The comparison of water quality in 2013 and 2014 years allows to conclude that the presence of more acidic environment and a high level of organic pollution in 2014 created favorable conditions for the growth and development not only for phytoplankton blooms, but also formacrophytes, which indicates degradation of the ecological conditions of the river.

\section{Acknowledgment}

The authors wish to express their thanks to GIS specialist, senior researcher Arakelyan Alexander for technical support in design of this paper.

\section{References}

[1] Standards of maximum permissible concentrations that often can be found in natural waters of chemicals and substances of human origin. Approved by the Ministry of Health of RA and registered by the Ministry of Justice of RA, 2002 (In Russian).

[2] Norms for assurance of river water quality for each river basin, depends on peculiarities of the area. The government decision of RA. 27.01.2011(In Armenian)

[3] Guidelines for collecting and processing of materials in hydrobiological studies on freshwater bodies. Phytoplankton and its products. Leningrad, 1981. (In Russian)

[4] Kiselev I. A. The study of plankton of water bodies, 1950. (In Russian)
[5] Zabelina, M. M., Kiselev I. A., Proshkina-Lavrenko A. I., Sheshukova V. S., Identification Book of Freshwater Algae of the Soviet Union, Diatoms. SovetskayaNauka, Moskva. 1951 (In Russian)

[6] Hambaryan L., Shahasizyan I. Freshwater algae families determinant, Yerevan, 2014,YSU published, 61p.

[7] Makovinska Y. Manual for quantitive and qualitive monitoring of freshwater ecosystems phytoplankton community, 2013, 103 p. (In Russian)

[8] Standardized methods for studying water quality. Part III. Methods of biological water analysis. Appendix 2: Atlas of saprobic organisms. Moscow, Sekretariat SEV, 1977. 228 p. (In Russian)

[9] Evaluation of nowadays natural contamination of Sevan Lake basin from Sotq ore deposit. Determination of natural background on the land and in the lake basin. Institute of Geological Sciences NAS RA and scientific research company Georisk. Final report. Contract YE 013/08. Yerevan 2008, p. 48 (In Armenian)

[10] Assessment of the impact of the planned processing plant and mining tails on the environment in the basin of Lake Sevan. Institute of Geological Sciences of Armenia. Final Report. Contract GPMG 007/09. Yerevan, 2009, 55p.

[11] Hambaryan L. et al. Heavy metal pollution of the catchment basins of the Voghchi and Meghriget rivers (Armenia) and risks to the environment associated with water pollution. Academic journal of science. 2013, CD-ROM. ISSN: 2165 6282: 2(2): 255-268.

[12] Hovhannisyan R.H. Book "Lake Sevan, yesterday, today.....". - Yerevan: Press of NAS RA, 1994, 479 pp.

[13] Hambaryan L., Hovsepyan A., Khachikyan T. Influence of Lake Sevan catchment basin phytoplankton community structure on the same of the lake. Regional workshop on "Sustainable Management of Water Resources and Conservation of Mountain Lake Ecosystem of Asian Countries", Yerevan, Armenia, 25-29 June, 2014, pp.102-112

[14] Barinova S.S., Medvedev L.A., Anisimov O.V. Algae biodiversity indicators of environment. - Tel Aviv, 2006. - 498 p (In Russian)

[15] Nikanorov A.M. Scientific bases of water quality monitoring, S-Peterburg, 2005, pp.367-372. (In Russian)

[16] Oswald W.J. Microalgae and waste water treatment. In: Borowitzka M.A., Borowitzka L.J (eds) Microalgae biotechnology. Cambridge University Press, Cambridge, 1998, pp. $691-707$ 